ECOLOGICA, Vol. 28, No 103 (2021), 387-394

https://doi.org/10.18485/ecologica.2021.28.103.8

Оригинални научни рад

УДК: 3.07:[004.7:17](497.11)

\title{
Етички аспект интензификације дигитализације за време пандемије COVID-19 у јавној управи Републике Србије
}

\section{Ethical aspect of digitalization intensification during COVID-19 in the public administration of the Republic of Serbia}

\author{
Доц. др Анђелка Рачић ${ }^{1 *}$, Доц. др Боривоје Балтезаревић \\ 1Правни фракултет, Универзитет „Мегатренд“, Београд, Србија / \\ Megatrend University, Faculty of Law, Belgrade, Serbia, e-mail: andjelka.racic@gmail.com \\ 2Факултет за менаџмент Сремски Карловци, Универзитет „Унион - Никола Тесла“, Србија / \\ Faculty of Management Sremski Karlovci, Union - Nikola Tesla University, Serbia, \\ e-mail: baltezb@yahoo.co.uk \\ *Аутор за преписку / Corresponding author
}

Рад примљен / Received: 20.12.2020, Рад прихваћен / Accepted: 08.07.2021.

\begin{abstract}
Сажетак: Појам дигитализација у свом основном означену представља превођење, трансформацију аналогног облика података без обзира да ли је у питању слика, текст или видео запис у дигитални облик. У савременом свету дигитализација је постала ствар свакодневице. Дигитализација омогућава брзину размене информација, пружања услуга и реализацију права грађана. Међутим, она повлачи за собом и питање колико је степен етике и даље заступљен у “брзом" раду и повезивању људи. Полазећи од чињенице да је први компјутер-рачунар за масовно коришћење стављен у употребу током 60тих година прошлог века, те да су у наредним деценијама достигнућа човечанства надмашила већину очекивања и амбициознијих снова, данас 2021 године након светске пошасти која попут атомске бомбе одјекнула али и оставила далекосежне и дугогодишње, деценијске промене вирус назван COVID-19, ушли смо у свет интензивне дигитализације и света електронске комуникације. COVID-19 је разрушио традиционалне облике комуникације у свим савременим друштва од економије преко едукације па до свакодневних социјалних комуникација. Од првих облика рестрикција и ограничења кретања, а што је свакако проузроковало низ осећаја нелагодности и фрустрације како међу обичним становништвом тако и међу пословним облицима комуникације, након првих пар месеци реорганизације рад у смеру обављања само "хитних" послова, те до већинске реорганизације послова на рад од куће, обраде податка електронским путем, као и пружања услуга, заокружило се у кратком временском периоду. Конкретно у периоду од марта до краја октобра 2020 године већина послова који су се до марта 2020 године обављали путем директних метода комуникације трансформисане су у дигиталне, а што је и те како омогућило већу ефикасност, економичност, али и транспарентност рада и то како приватних организација тако и целокупне јавне управе Републике Србије, а о чему ће бити посебно речи у раду.
\end{abstract}

Кључне речи: етички аспект, јавна управа, влада Републике Србије, дигитализација, е-управа, COVID-19.

Abstract: The term digitization in its basic meaning represents translation, transformation of analogue data form, whether it is images, text or video to digital form. In modern world, digitization has become a matter of everyday life. Digitization gave more speed of exchange information, providing services and realization of citizens' rights. However, it entails and the question of how much steppe ethics remains represented in the "fast" work and connecting people. Starting from the fact that the first computer-computer for mass use, and that in the coming decades of humanity have surpassed most of the expectations and more ambitious dreams, today 2021 after the world's plague exceeded but left as the atomic bomb Farmer and many years, dialectical changes Virus called Covid-19, we entered the world of intensive digitization and world of electronic communications. COVER-19 has destroyed traditional forms of communication in all modern societies from the economy through education and everyday social communications. From the first forms of restrictions and restrictions on the feelings of discomfort and frustration as well as among the ordinary population, after the first few months of reorganization, finished only "emergency" jobs, reorganization regular job in Work at home, data processing electronically, 
as well as service delivery, has rounded in a short period of time. The most effective digitization was from March to the end of October 2020. In that time,the most public administration jobs were transformed into digital service. Efficiency, economy and transparency of public administration in the Republic of Serbia were in the high level of realization.

Keywords: ethical aspect, public administration, government of the Republic of Serbia, digitalization, e-government, COVID-19.

\section{УВОД / INTRODUCTION}

Влада Републике Србије је још током 2001. године најавила рефоорм јавне управе (тад називане државна управа), тај процес је био дуг, некад са више, а некад са мање успеха. Наредних година, а нарочито од 2018 године инсистирало се на дигитализацији јавне управе и успостављена је е-управа. Конкретно, иако је 2017 године усвојен Закон о електронској канцеларији, већина послова јавне управе се одвијала директном комуникацију између заинтересованих страна. Међутим, појавом вируса COVID-19, послови којима се реализује концепт "Добре јавне управе" нису могли да чекају, као ни права грађана, те је уз велики напор Владе Републике Србије, али и потреба грађа Републике Србије интензивирана, не само дигитализација јавне управе, већ и њена употреба у свакодневном животу. Интензивном дигитализацијом јавне управе чекање на шалтерима, редови и пробијање рокова су, ако не нулирани, а оно минимизирани, чиме је великом брзином у кратком року у великом степену постигнута парадигма добре јавне управе, ефикасност и економичност рада уз задовољење права грађана, а што је истовремено и једна од кључних тачка Стратегије одрживог развоја Републике Србије на који се чекало деценијама, а све уз задовољење основних начела Кодекса понашања државних службеника.

Република Србија је на путу евроинтеграција. Децидним потписивањем Уговора о придруживању Република Србија се обавезала на низ промена којима ће се изједначити са нормативом Европске уније, као и успоставити окружење и услове деловања једнаке правилима и успостављеним стандардима Европске уније. Једна од битних тачака преговора и успостављања европских стандарда је и питање екологије, те је Влада Републике Србије усвојила између осталог Стратегију одрживог развоја, низ закона и подзаконских аката у области екологије. У усвојеној Националној стратегији одрживог развоја за период од 2008. до 2017. године се као основни циљ истиче уравнотежење: „...три кључна фрактора, тј. три стуба одрживог развоја: одрживи развој економије, привреде и технологије, одрживи развој друштва на бази социјалне равнотеже и заштита животне средине уз рационално располагање природним ресурсима. Истовремено, циљ стратегије је да споји та три стуба у целину коју ће подржавати одговарајуће институције“ (стр. 3). Надаље је истакнуто да ,једнакост и разумевање међузависности људи унутар заједнице представљају основни предуслов прихватљивог квалитета живота, што је у суштини први циљ развоја" (Стратегија одрживог развоја), а који води друштвеном благостању „... које у контексту Стратегије подразумева оне аспекте живота људи око којих постоји свеобухватно сагласје у друштву и да представљају најзначајније предуслове за лични осећај среће, квалитета живота и добробити појединца“" (Стратегија одрживог развоја). Свакако да се ови циљеви у свом пуном именитељу не могу реализовати занемаривањем етичких постулата који се тичу професионалног, непристрасног, политички неутралног поступања, те једнаког поступања према свим странкама без давања приоритета због личних интереса и побуда.

Друштвено благостање је циљ сваке заједнице, а методи и средства до његове реализације су различити. Да би се остварило друштвено благостање потребно је за почетак поставити питање ко су њени субјекти, те средства која користе за реализацију постављених циљева и на крају које су применљиве методе.

С тим у вези, а полазећи од одредби члана 4 Закона о заштити животне средине (2004-2018) субјекти система животне средине су: „.. 1) Република Србија; 2) аутономна покрајина; 3) општина, односно град (у даљем тексту: јединица локалне самоуправе); 4) предузећа, друга домаћа и страна правна лица и предузетници који у обављању привредне и друге делатности користе природне вредности, угрожавају или загађују животну средину (у даљем тексту: правна и фризичка лица); 5) научне и стручне организације и друге јавне службе; 6) грађанин, групе грађана, њихова удружења, професионалне или друге организације“. Са друге стране, а полазећи од чињенице да „Јавна управа... обухвата државне органе и самосталне и независне организације и 
тела чији састав бира Народна скупштина (надзорна и регулаторна тела), органе, организације и службе аутономне покрајине и јединице локалне самоуправе, јавне агенције и организације на које се примењују прописи о јавним агенцијама, а чији је оснивач Република Србија или аутономна покрајина или јединица локалне самоуправе и предузећа, установе, организације и појединци којима су поверена јавна овлашћења“ (Закон о Националној академији за јавну управу, 2017, члан 2), долазимо до закључка да су субјекти система животне средине целокупна јавна управа и њени крајњи корисници-грађани. Тачније, да субјекти система животне средине сви они који живе и раде на територији Републике Србије, (на истој сталној адреси или живе привремено и само обављају повремене и привремене послове) имају законску обавезу да својим позитивним опхођењем према животној средини, те активним деловањем, али и пропагирањем еколошке свести, теже реализацији друштва благостања.

Када су у питању средства која се користе за реализацију друштва благостање, у Републици Србији, дуги низ године егзистирају две врсте финансирања за све врсте пројеката и рада како Владе Републике Србије, тако и свих органа, организација и невладиног сектора. То су буџетска средства Републике Србије и стране донације.

Када говоримо о методама реализације друштвеног благостања, она су великим делом условљена друштвеним областима рада и њеним усвојеним пропратним стратегијама, агендама и акционим плановима.

Поред наведеног, путем рада на здравој животној средини, води, ваздуху, контролисањем отпада и комуналних вода, односно синергијом свих субјеката животне средине и њихових средстава уз економично и рационално деловање уз примену конкретних методологија рада реализоваће се идеја друштвеног благостања. Приликом примене конкретних метода рада сваки субјекат се мора руководити и етичким првилима своје струке. Истицањем и исказивањем нулте толеранције на непрофресионалност, корупцију, сукоб интереса, занемаривање јавног добра и јавних интереса, може се постићи држава благостања.

Разлог повезивања појмова субјеката система животне средине и јавне управе, налази практично објашњење. Конкретно, док са једне стране имамо дефиницију друштвеног благостања у Стратегији о одрживом развоју, која услед фринансијских и техничких немогућности, није наишла на конкретну примену у реалном свакодневном животу како појединаца, тако и привредних друштава, организација, и локалних заједница, са друге стране, под утицајем реформе јавне управе, управо идеја друштвеног благостања постављена кроз нови концепт јавне управе у Републици Србији је кренула ка успешној реализацији.

Напорима Владе Републике Србије усвојена је Стратегија рефрорме јавне управе која једнако као и претходно наведена Стратегија истиче благостање људи као доминантни именитељ реформе.

Уколико посматрамо паралелно постављене циљеве ове две стратегије можемо закључити да обе иду истим колосеком, реализацији истог циља - опште добробити грађана Републике Србије. Разлике између њих налазе се у степену њихове реализације. Док Стратегија одрживог развоја није у великом делу реализовала своје постављене циљеве нити се већини истих приближила, са друге стране Стратегија реформе јавне управе је и те како реализована, у нешто дужем року од предвиђеног, али са великом помаком. Једна од тачака високог степена реализације реформе јавне управе је дигитализација јавне управе у Републици Србији, на којој се управо и инсистира у новом модерном добу.

Дигитализација је посебно интензивирана током 2020 године, време COVID-19. Међутим, иако реализација дигитализације у Републици Србији бележи успех током 2020 године, тај резултат је добијен током дуготрајног рада Владе Републике Србије, превасходно на рефоорми јавне управе. Уз дигитализацију јавне управе и задовољење сегмента професионалности, економичности и ефикасности у целости се приступило и реализацији етичких постулата. Брисањем директних контаката између запосленог у јавној управи и грађана, степен корупције, личних веза и познанаства, а тиме и утицаја на рад јавне управе је минимизиран. Успостављена је већа контрола, пре свега номенклатурна када је који захтев поднет, када је ажуриран, када је по њему поступљено и када је целокупни процес арихивиран. Ма колико службеници у јавној управи поштовали Кодекс понашања државних службеника којима се деклараторно истиче професионалност, једнакост поступања, непристрасност и слично, доминацијом дигитализације успостављена је већа контрола и увид у рад сваког службеника појединачно, а тиме и вечи степен транспарентности рада служби. Етика рада јавне управе је сада лако проверљива и мерљива. Интензивна дигитализација је томе допринела. 
1. РЕФОРМА JАВНЕ УПРАВЕ $И$

ДИГИТАЛИЗАЦИЈА РЕПУБЛИКЕ СРБИЈЕ /

PUBLIC ADMINISTRATION REFORM AND

DIGITALIZATION OF THE REPUBLIC OF SERBIA

Држава организује јавну управу у складу с политичким, државним и друштвеним уређењем прокламованим највишим правним актима. Закони и подзаконски акти којима се уређује јавна управа треба да представљају реликт задовољења основних потреба грађана у савременом добу. Тек након упознавања политичког, државног и друштвеног уређења државе можемо рећи да ли је њена јавна управа добра или не.

Наступањем политичких промена 2000. године, променом политичког система и отварањем граница, али и продирањем нових идеја, у Републици Србији је започео процес преображаја јавне управе, од основне поставке као реперкусора власти и чистог извршиоца налога државе до сервиса грађана. Међутим, о реалној реформи јавне управе у Републици Србији се може говорити тек од 2012. године и конкретне примене мера за реализацију Стратегије реформе јавне управе уз пропратне Анексе.

Из епистемиолошког угла, изабран је најбољи модел реформе јавне управе, уз одабир адекватних мера којима ће се Стратегија спровести. Конкретно Република Србија је одредила свој план и циљ реформе, издвојила средства из буџета уз наменско коришћење донација Европске уније, којима се финансира реформа јавне управе. Финансирање од стране Европске уније за реформу јавне управе је неминовно, али и пожељно. Разлог томе се налази у чињеници да Република Србија има специфричну историју настанка демократског друштвеног и државног уређења, али истовремено и велики утицај страног фактора на поједине политичке одлуке. Разлог страног утицаја је геополитички положај Републике Србије, која је „запад на истоку“ и „исток на западу“, простире се ка Европи, али представља врата ка Азији.

Вођена правилима Европске уније, Република Србија је, узимајући у обзир добре и лоше елементе могућих модела јавне управе, усвојила Стратегијска документа у области рефрорме јавне управе који су највише одговарали њеном политичко-правном систему. Стратегијска документа су обухватала Стратегију и акционе планове реформе, који су еволуирали од 2012 године до 2018 године односно 2019. године са последњим изменама и допунама.

Иако је прва Стратегија усвојена 2012 године, након 2012. године, под утицајем промењених политичких околности изостали су редовни извештаји о реализацији реформе државне управе од 2012 до 2014. године, тако да је тек 2014. године усвојен и обезбеђен наставак започетих реформских активности, који је проширен на целокупни систем јавне управе. Кључни разлог проширења предмета Стратегије с државне на јавну управу односи се првенствено на потребу обезбеђења функционалног јединства и стандарда квалитета активности којима се врше одређене врсте управних послова и јавних овлашћења, независно од субјеката (Стратегија реформе јавне управе у Републици Србији, 2014-2018). Уз даљи развој идеје државе благостања уз активно прихватање модернизације државе, државног система и целокупног друштва, Стратегија реформе јавне управе од 2018. године по први пут презентује идеју дигитализације јавне управе, увођење система е-управе, а све у циљу ефикасности и економичност рада јавне управе Републике Србије чиме ће се не само уштедети средства буџета, већ се истима, а што је најбитнији циљ, омогућити грађанима брже задовољење њихових потреба када су у питању послови јавне управе.

Први корак ка конкретизацији овог циља је усвајање Закона о електронској управи, те увођење сајта е-управа, чији је примена све до 2020 године била задовољавајућа, али не и у довољној мери велика. Основни проблем се налази у околности, да су поједини грађани и даље користили непосредни облик комуникације са јавним сектором, подношењем правних аката фризички не полажући веру у нови „виртуални систем рада” јавне управе. Осим тога, велики број грађана није имао основна знања коришћења интернет комуникације, нити је имао интернет конекцију. С тим у вези према Стратегији развоја дигиталних вештина Републике Србије усвојеном марта 2020. године се наводи да: „... према резултатима овог истраживања, у Републици Србији 72,9\% домаћинстава поседује интернет прикључак... Интернет услуге електронске управе користи 37,3\% популације уместо да остварује личне контакте или да посећује јавне установе или органе администрације“. Како би се решио овај проблем именованом Стратегијом је предложено предузимање конкретних мера међу којима су најзначајније: смањење цена телекомуникационих услуга, развој мреже е-центра и разграњивање инфро центара са е-услугама и то полазећи од најнижег нивоа локалне самоуправе.

Усвојена Стратегија е-управе заснива се на истраживањима спроведеним током 2014. године. У међувремену је инфрраструктура знатно побољшана, али остао је елемент спотицања - слаба 
писменост грађана у домену информационих технологија и то на свим нивоима.

Ипак, напори рада Владе нису изостајали, иако поверење грађана није било задобијено у систему дигитализације. У периоду од 2018. до 2020. године усвојен је низ закона, подзаконских аката, стратегија и акционих планова из више различитих области деловања. Међу њима су Стратегија развоја информационог друштва у Републици Србији до 2020. године (2010), Стратегија развоја електронских комуникација у Републици Србији од 2010. до 2020. године (2010) и Стратегија развоја информационе безбедности у Републици Србији за период од 2017. до 2020. године (2017), као и закони из ове области - Закон о електронском документу, електронској идентификацији и услугама од поверења у електронском пословању (2017) и Закон о електронској управи (2018). Поред наведеног Министарство за туризам у наведеном периоду начинило је јасан инфраструктурни план за постављање и развој дигиталних мрежних преносника.

Дакле, под утицајем идеје ефикасности, економичности и транспарентности, као именитеља реформе јавне управе изнедрене су промене, највише у законодавном смислу, у циљу дигитализације, а тиме и модернизације Републике Србије.

\section{2. ДИГИТАЛИЗАЦИЈА И COVID-19 / DIGITALIZATION AND COVID-19}

Дигитални облик комуникације и презентације до почетка 2020. године је изгледао као тешко остварљив циљ. Међутим, под утицајем светске пошасти пандемије COVID-19 која је уништила некадашње облике традиционалног живота и комуникације, наступила је нова сфере развоја и напретка друштва у облику дигиталног повезивања на свим нивоима.

Наступањем COVID-19 промене су биле неминовне. COVID-19 је донео низ промена човечанству. У почетку, прво усвојене мере „затварања“ локала, јавних установа, граница, али и ограничавање слободе кретања грађанима, посматране су као привремене. Привременост се проширила на годину дана и дуже, без јасне идеје када ће бити укинуте. Већина влада света су усвојиле мере „lock down“ а тим путем је кренула и Влада Републике Србије.

Увођење, ванредног стања 16. марта 2020. до 6. маја 2020. године, ограничен је био рад свих установа, али и кретање грађана. Све се могло издржати извесно време, али живот и свакодневне обавезе, права и дужности нису могле даље да чекају. Морао се изнаћи начин задово- љења истих, али без одласка на „лице места“. Као једино, али уједно и прихватљиво решење наметнула се интензивнија дигитализација рада свих органа, организација, управе и свих „сервиса“ грађана. Поред деклараторне исказане потребе, основе дигитализације су већ биле постављене. Било је потребно интензивније исте применити у пракси и све закаснеле мере, предвиђене већ усвојеним акционим плановима и другим правним актима, применити. Одлагање више није било могуће. Права грађана су одлагана, права на друштвено благостање, без обзира колико оно изгледало ирелевантно у тренутку светске пошасти. Од тренутка када грађани више нису могли да оду до службеника (било у полицију, елетктродистрибуцију, општине...) морали су да прихвате дигитални облик комуникације, а држава као један од доминантних субјеката животне средине и примарни обавезујући субјект друштва благостања, морала је то да обезбеди. Прионуло се на интензивну дигитализацију.

Иако је дигитализација заступљена већ дуги низ година превасходно у свету, а једним делом и у Републици Србији, као права експлозија проширила се у неколико недеља у областима за које су биле потребе године успостављања. Поред Владе које је пропагирала дигитализацију и унапредила дигитални сервис услуга на свим нивоима, одазив грађана је коначно био позитиван. Најбољи пример за то се види упоређивањем података наведених у Стратегији о е-управи, која је усвојена 2015. године и заснована највећим делом на постављеним циљевима, у којој се наводи да се до 2018. године планира да „... 40\% грађана редовно користи услуге еУправе, 85\% привредних субјеката редовно користи услуге еУправе, електронске услуге расположиве су како за кориснике у Републици Србији, тако и за кориснике у иностранству“ (Стратегија развоја електронске управе у Републици Србији за период од 2015-2018. године и акциони план за спровођење стратегије за период од 2015-2016. године, стр 19), што ће представљати основни показатељ добре реализације Стратегије е-управе. Овај циљ није остварен 2018. године, али зато према ex/post извештају из 2020. године Републичког завода за статистику „у Републици Србији преко 3.200.000 лица користи рачунар сваког или скоро сваког дана у 2020. години. 37\% интернет популације у 2020. години користи услуге е-управе. У последња три месеца 36,1\% корисника интернета је куповало/поручивало робу или услуге путем интернета“ (https://www.stat.gov.rs/). 
Дакле, употреба дигиталне комуникације је и те како интензивирана, а тиме почиње да даје и позитивне повратне реакције њених корисника.

Најбољи пример успешности интензивне дигитализације је доступност информација на сајту https://www.digitalnasolidarnost.gov.rs/\#digitalnasoli darnost што је омогућило виртуелну едукацију, посету музејима и културним догађајима, приступ пијаци, раду од куће и сл. Портал е-управа који је дугогодишњи пројекат Владе Републике Србије, сада је добио на пуном значају, јер се путем истог омогућава добијање свих правно нормативних аката без којих је немогуће организовати свакодневни живот, а са друге стране принцип социјалне дистанце и заштите јавног здравља је очуван. Путем наведеног портала се може извршити упис у матичне књиге рођених, пријавити привремени боравак странца, дете уписати у вртић, добити одбијеница за исто, регистровати возило, те се „захваљујући централизацији података, грађанима и привреди омогућава да „на клик” виде све своје пореске обавезе на територији Републике Србије, и да електронским путем поднесу пријаву за утврђивање пореза на имовину (https://euprava.gov.rs/usluge/5194)“, као и да добију низ одговора на питања које се тичу процедуре око куповине станова, трудничког боловања, одласка на порољиско отсуство и сл. Свакако најзначајнија је пријава за Covid-19 тестирање и вакцинацију, путем којих се ефикасно и економично обавља превенција здравља целокупне државе Републике Србије, а тиме индиректно и циљ друштва благостања.

Колики је степен интензивирања дигитализације у последњем приоду у Републици Србији најбољи показатељ је извештај Уједињених Нација - United Nations eGovernment Survey 2020, у којем је исказана успешност напретка рада електронске управе у „193 држава чланица Уједињених нација, Србија се нашла у првој групи, тј. групи земаља са највишим индексом електронских услуга... Оно што је ове године новитет, је да се по апсолутној вредности индекса електронских услуга (OSI) Србија налази испред 12 земаља чланица Европске Уније, наиме Ирске, Луксембурга, Бугарске и Хрватске (које су такође у групи са највишим индексом), као и испред Немачке, Мађарске, Чешке, Румуније, Словачке, Грчке, Белгије и Летоније (које су у нижој групи) (https://www.ite.gov.rs/vest/5626).

Тај процес није стао, већ се он даље шири и то конкретно путем пружања јасних инструкција грађанима на локалном нивоу како да користе портал е-управа. Конкретно, локалне самоупрве су ангажовале велики број шалтерских службе- ника који ће помагати и давати инструкције грађанима око начина коришћења апликације е-управа. Систем рада је поједностављен на тај начин што се узимањем личне карте на шалтеру, добија апликација на телефону, корисничко име и лозинка као и инструкције како исте користити. Уз поједностављену непосредну обуку грађана, може се тек очекивати даљи просперитет и употреба дигиталног облика комуникације на релацији грађанин - јавна управа.

Дигитализација рада школа и дигитализација уџбеника је током 2020 године на пиједесталу успешности. У том смислу према расположивим подацима тренутно се ради на пројекту продужетка буџетирања допунског броја дигиталних учионица, а циљ је да 2021. године имамо комплетну дигиталну просвету (https://www.srbija.gov. rs/vest/407169). Такође, „Европска инвестициона банка (ЕИБ) је током 2020 године за дигитализацију и модернизацију школа Републике Србије укупно донирала 65 милиона евра. Дигитализација и модернизација се заснива на увођењу бежичаног интернета. Такође, као битан елемент се истиче и обука наставног особља за примену истог. „Разлози за обуку наставног кадра су произашли из истраживања спроведених током 2018-2019 године према којима већина наставног особља има само основна знања и способности за примену дигиталних вештина, те да иако у својим кабинетима имају успостављену техничку могућност за одржавање наставе уз помоћ дигиталних „помагала“ иста нису коришћена, те се и даље примењивао класичан систем наставе помоћу „табле и креде“. До 2021 године „ЕИБ је уложила 50 милиона евра у модернизацију српских школа и тиме побољшала услове за око 28.000 ученика у преко 200 образовних установа. Улагањем 200 милиона евра у обнову сектора за истраживање и развој у Србији, створена је дугорочна платформа за развој науке у свим главним областима“ (https://www.eib.org/en/press/all/).

Поред примене дигитализације у школству, велики значај има и дигитализација рада већине републичких органа и организација, међу којима је дигитализација Катастра непокретности. У периоду трајања ванредног стања остварене су „5.343 купопродаје непокретности, катастру су те уговоре доставили јавни бележници путем еШалтера“ (https://rgz.gov.rs/content/Datoteke). Вођени искуством рада током ванредног стања у Републици Србији убрзана је модернизација и дигитализација рада Катастра, јер се сада већина пословне комуникације и рада заснива на дигиталној обради података и њиховом дигиталном пријему. Covid-19 пандемија је представљала тест за пот- 
пуни прелазак на дигитални облик рада, а што се и догодило од јануара 2021. године када се прешло искључиво на рад путем интернет платфрорме.

Дигитализација је доминирала у још једном сегменту, а то је заступљеност комуникације путем on-line састанака и конференција, који је омогућио успостављање нових партнерских односа и даљи развој и унапређење већ раније закључених. Организоване on-line конференције су окупљале велики број учесника, чиме су задовољена два циља и то: заштита здравља уз примену принципа социјалне дистанце, али и задовољење социјалног елемента људи - одржавање комуникације о примарним сегментима живота и њихово унапређење. On-line конференцијама је доказано да кад људи желе да комуницирају, нарочито на тему реализације друштвеног благостања и то у време „немила“, увек могу да пронађу метод и средство за то.

Целокупни процес дигитализације у Републици Србији је финансиран из два доминанта извора средстава и то: буџета Републике Србије и страних донација од којих чак 100 милиона евра донирала Европска унија. Интензивном дигитализацијом у великом степену су задовољена људска права грађана на свим нивома јавне управе, а и више од тога, етички аспект јавне управе који се тиче поступања јавног службеника при задовољењу права странка тако да странка, грађанин ефикасније и једноставније заштити своја права и правне, интерсе је у целости реализован. Такође, аспет етике јавне управе да се приликом свог рада руководи најбољим јавним интересом је поспешен. Разлог, дигитализација је омогућила да се задовоље лична права грађана, али и очува социјална дистанца и јавно здравље колико је пандемија то дозволила.

\section{ЗАКЉУЧАК / CONCLUSION}

Дигитализација је део савременог, модерног доба. До пре пар година је била непознаница у Републици Србији, али прихватајући нови концепт јавне управе као сервиса грађана, те прихватања стандарда Европске уније и жеље да Република Србија иде у добром колосеку евроинтеграција уз реализацију циља државе благостања, Влада Републике Србије је у својим правним актима поставила базу за успостављање и развој дигиталног система у Републици Србији. Било потребно посегнути финансијска, техничка и едукативна средства. Разлог томе се налазио у чињеници да се већина административних послова, било везаних за приватни, било за јавни сектор, одвијала непосредним путем, одласком до жељене институције, папирним подношењем захтева, чекањем у редовима. Тренутком објављивања Covid-19 пандемије, увођењем ванредног стања у Републици Србији од 16. марта до 6. маја 2020. године, а тиме и социјалне дистанце, претходно успостављени систем комуникације је морао бити измењен. Непосредни контакти више нису били дозвољени. Једни могући прихватљив облик замене стандардног облика комуникације је било успостављање дигиталне платформе на свим нивоима. Као неминовност наступила је интензификација дигитализације јавне управе. Грађани који више нису могли да оду до службеника (у полицији, елетктродистрибуцији, општини, ...) морали су да прихвате дигитални облик комуникације.

Током пандемије већина органа и организација јавне управе је успоставила дигитални приступ својим услугама: од дигиталног школовања до укњижбе некретнина и продаје, организовања вакцинације, уписа у вртић и сл. Са друге стране, сегменти јавне управе, који до 2020. године нису свој рад организовали у дигиталном облику, у циљу омогућавања свог рада и задржавања како финансијског статуса, тако и реализације ефективности рада, прионули су на дигитализацију својих услуга. Резултат је уследио. Према глобалном извештају Уједињених Нација United Nations eGovernment Survey 2020, Република Србија се нашла у првој групи земаља од 193 које се успешно унапредиле рад своје еуправе. Успех није дошао изненада, он представља само интензивније коришћења већ успостављене базе. Наиме, Република Србија је имала законску и стратегијску основу за дигитализацију и то у домену јавне управе, а што је представљало најбољу могућу, а у датом тренутку и једину солуцију. Дигитализација јавне управе је у Републици Србији дуг процес, некада је био са више а некада са мање успеха, али и поред свих потешкоћа које се могу разврстати на финансијске, техничке и субјективне, на дигитализацији се инсистирало и она се још увек унапређује. Био је потребан систематичан приступ целокупној идеји дигитализације јавне управе генерално. Наиме, усвајањем Стратегије реформе јавне управе од 2018. године и ревидираним текстом 2019. године први пут се у Републици Србије помиње е-управа. Наведеном Стратегијом, као и Националном стратегијом одрживог развоја за период од 2008. до 2017. године истакнута је идеја државе благостања у којој ће бити задовољене све потребе грађана на највишем нивоу и то од свакодневних потреба (одлазак на пијацу, коришћење здравог ваздуха и чисте воде, град без саобраћајне гужве и буке) па све до универзалних права грађана. 
Идеја друштва благостања (дефинисана као опште добро грађана) није могла бити одлагана, па макар се нашла пред препреком светске пошасти Covid-19. Разлог за то је једноставан, држава благостања је епицентар свакодневног животног грађанског битисања. Држава благостања омогућава појединцу да свакога дана у здравом, продуктивном окружењу реализује своја права и животне потребне на економичан и ефикасан начин. Дигитализација током пандемије Covid-19 је то омогућила на најбољи начин. Сегмент социјалне дистанце, а тиме и заштите јавног здравља је задовољен, а реализација права грађана максимизирана уз смањен утрошак времена и новца. Дигитализација је реинкарнација животне средине, јер се уз помоћ ње смањује низ нуспојава као последица непосредне комуникације људе (коришћење превоза, утрошак папира, стварање отпада и сл.). Дигитализација је нови озонски омотач планете Земље. Она је омогућила да етички аспекти непристрасности, једнаког поступања према странкама, политичка непристрасност, али и поступање вођењем јавног интереса добију своју пуну примену и не буду ствар личног понашања јавног службеника, већ транспарентни и лако проверљиви. Уз помоћ дигитализације поступљено је по правним нормама, али етички аспекти јавне управе и запослених у њој, су донели психолошку победу над светском пошасти.

Интензификација дигитализације у Србији још увек наилази, на низ изазова који се превасходно односе на заштиту личних података и недостатак опште компјутерске оспособљености грађана. Такође, велики изазов је представља и техничка основа и могућност за њено унапређење. Развојем инфраструктуре, али уз поштовање Европског зеленог договора, дигитализација рада јавне управе за време COVID-19 у Републици Србији је унапређена.

\section{ЛИТЕРАТУРA / REFERENCES}

[1] Закон о електронском документу, електронској идентифрикацији и услугама од поверења у електронском пословању, (2017), Службени әласник PC, број 94/17

[2] Закон о електронској управи, (2018), Службени гласник PC, број 27/18.

[3] Закон о заштити животне средине, Службени гласник PC, бр. 135/2004, 36/2009, 36/2009 - др. закон, 72/2009 - др. закон, 43/2011 - одлука УС, 14/2016, 76/2018, 95/2018 - др. закон и 95/2018 - др. Закон
[4] Закон о Националној академији за јавну управу, Службени гласник PC, бр. 94/2017

[5] Стратегија одрживог развоја, http://www.zurbnis.rs/zakoni/Nacionalna\%20strate gija\%20odrzivog\%20razvoja.pdf доступно дана 28.02.2021. године

[6] Стратегија реформе јавне управе у Републици Србији, Службени гласник PC, бр. 9/14, 42/14 исправка, 54/2018

[7] Стратегија развоја информационог друштва у Републици Србији до 2020. године, (2010), Службени гласник PC, број 51/10.

[8] Стратегија развоја електронских комуникација у Републици Србији од 2010. до 2020. године, (2010), Службени гласник PC, број 68/10.

[9] Стратегија развоја информационе безбедности у Републици Србији за период од 2017. до 2020. године, (2017), Службени гласник PC, број $53 / 17$.

[10] Стратегија развоја електронске управе у Републици Србији за период од 2015-2018. године и акциони план за спровођење стратегије за период од 2015-2016. године, http://mduls.gov.rs/wp-content/uploads/strategijarazvoja-euprave-sa-ap-2015-2018.pdf доступно дана 11.02.2021. године

[11] Стратегија развоја дигиталних вештина Републике Србије (2020), https://www.pravno-informa cioni.sistem.rs/SIGlasnikPortal/eli/rep/sgrs/vlada/ strategija/2020/21/2/reg, доступно дана 15.02.2021. године

[12] https://www.stat.gov.rs/sr-latn/vesti/20200922upotreba-ikt-a-pojedinci-2020/?s=2702, доступно дана 15.02.2021. године

[13] https://euprava.gov.rs/usluge/5194, доступно дана 17.02.2021. године

[14] https://www.ite.gov.rs/vest/5626/u-domu-narodneskupstite-odrzano-prvo-javno-slusanjedigitalizacija-u-srbiji-gde-smo-danas-.php, доступно дана 01.03.2021. године

[15] https://www.srbija.gov.rs/vest/407169/do-2021godine-kompletna-digitalizacija-prosvete.php, доступно дана 25.02.2021. године

[16] https://www.eib.org/en/press/all/2020-217-eibsupports-digitalisation-of-serbian-schools-witheur65-million?lang=sr, доступно дана 05.02.2021. године

[17] https://rgz.gov.rs/content/Datoteke/RGZinfo/srpski /2020/RGZ\%20info5_2020.pdf. доступно дана 01.02.2021. године

[18] https://www.digitalnasolidarnost.gov.rs/\#digitalnas olidarnost. 